\title{
ARTICLE
}

\section{Tábor v Letech jako „neexistující pseudokoncentrák“: analýza proměny letských narativů ${ }^{1}$}

The Lety camp as a "nonexistent pseudo concentration camp": An analysis of the changing Lety narratives

\section{TEREZA VAŇÁČOVÁ \& VLADIMÍR NAXERA²}

Department of Politics and International Relations, Faculty of Arts, University of West Bohemia, Czech Republic

\begin{abstract}
Interpreting and staging the past is an integral part of politics in its different forms. Selected historical events that are attached greater importance have often been contested politically. In the last two decades or so, clashes over the past have escalated in most consolidated democracies and have become more closely linked with other dimensions of political conflict. In the already consolidated Czech democracy, disputes have reopened over both the Communist regime and a much older past, with history fully entering the political agenda. These conflicts have been centred on both the historical subjects and fundamental points of collective memory, and on locations related to that memory and history. In a specific time and space, those places represent a certain tale, a certain interpretation of historical events, and at the same time allow for the development of other tales, often updated and in some cases politically contested. The forms and nature of the physical places of collective memory may vary. Firstly, these may be places "where bodies lie or have lain" - mass graves, destroyed communities or other places of collective suffering. This paper tackles this issue and analyses the narratives constructed by leading Czech politicians of the WWII Roma concentration camp in Lety. It presents the main arguments of the competing narratives and their changes throughout the post-Communist period.
\end{abstract}

\section{Keywords}

Roma holocaust, Lety concentration camp, use of history, human remains, sites of trauma, memorial site, Czech politics, collective memory

DOI: https://doi.org/10.24132/cejop_2021_4

How to cite: Vaňáčová, T. and Naxera, V. 2021. “Tábor v Letech jako „neexistující pseudokoncentrák“: analýza proměny letských narativů." Central European Journal of Politics 7 (1): 76-103. DOI: 10.24132/cejop_2021_4

\footnotetext{
${ }^{1}$ Text je dílčím výstupem projektu podpořeného GA ČR, č. 18-08605S „Instrumentální politizace dějin jako legitimizační nástroj politických režimů“.

${ }^{2}$ Kontakt: PhDr. Vladimír Naxera, Ph.D., odborný asistent, Katedra politologie a mezinárodních vztahů, Fakulta filozofická, Západočeská univerzita v Plzni, Jungmannova 1, 30100 Plzeň, Česká republika. E-mail: vnaxera@kap.zcu.cz
} 


\section{1. Úvod}

Připomínání (nebo naopak záměrně vytěsňování) zlomových historických událostí je standardním nástrojem, který slouží k budování národní mytologie a utváření kolektivní identity (např. Hroch 2009). Jedním z důležitých milníků evropských dějin je beze sporu druhá světová válka, nejničivější konflikt v lidských dějinách, jehož odkaz je v rámci jednotlivých národních mytologií, kolektivních pamětí nebo sakrální topografii (nejen evropského) prostoru silně př́tomný i v současnosti (např. Roediger et al. 2019; Naxera a Krčál 2021; Bernstein 2015). Připomínání a vzpomínání na druhoválečné události plní v rámci evropských společností důležitou roli ve vztahu k usmíření a jasnému vymezení se proti minulosti, slouží také jako zdroj a manifestace „poučení se z minulosti“, ale také jako vděčný předmět kulturních válek. Jedním z aspektů druhé světové války, kterému je věnováno mnoho pozornosti, je holokaust (Diner 2003: 36; Probst 2003: 53; Garsztecki 2012). Na druhou stranu některé jiné aspekty této dějinné epochy bývají z repertoáru epizod relativně nedávné minulosti vytlačovány. Jednou z těchto epizod, na které se po dlouhou dobu „zapomnělo“, je v českém př́ípadě mimo jiné romský holokaust, jehož význam je marginalizován už tím, že samotný výraz „holokaust“ bývá často i ze strany vědců vztažen výhradně ke genocidě Židů (Sniegon 2014: 135-136). Romský holokaust je v českém veřejném diskurzu reprezentovaný významným místem kolektivní paměti (srov. Nora 1989), bývalým táborem v Letech u Písku, který představuje klasické trauma site (srov. Violi 2012) spojené s dead bodies (srov. Verdery 1999; podrobněji viz následující část).

Diskuze o osudu místa, na kterém v době druhé světové války tábor stával, dobře symbolizuje celou diskuzi o romském holokaustu a do značné míry též vypovídá o postavení Romů v české společnosti. Romská otázka byla před rokem 1989 ve společnosti tabuizována. Samotnému romskému holokaustu sice pozornost věnována byla i za komunistického režimu, nicméně pouze na úrovni historiků nebo archiváŕů a nedostávalo se mu publicity v médiích (Valenta 1999: 11). Pro velkou část společnosti tak nebyl romský holokaust součástí historické paměti. Tomu odpovídá i skutečnost, že na místě bývalého tábora vyrostl v 70. letech velkokapacitní vepřín. Po sametové revoluci se sice situace změnila, ale osudům a situaci Romů za druhé světové války stále není věnován stejný prostor jako jiným skupinám obyvatel Československa v tomto období.

$\mathrm{V}$ př́padě, že se otázkou romského holokaustu média nebo politici zabývají, dochází často k odmítání existence romského holokaustu, znevažování utrpení jeho obětí nebo popírání a potlačování českého podílu a viny na likvidaci romského obyvatelstva během okupace. Medializace tématu po roce 1989 souvisí zejména s otázkou vybudování památníku v oblasti bývalého romského tábora v Letech u Písku. Právě památníky totiž ukazují povahu a cíle institucí, v jejichž době vznikly (Oláh 2013: 734), a současně uchovávají tyto postoje a hodnoty pro budoucí společnost. Zároveň lze památníky a další 
místa paměti vnímat jako výsledek snahy státních aparátů dosáhnout z jejich pohledu požadované interpretace minulosti (D'Orsi 2015: 173).

Obsah diskuze související s tématem romského holokaustu se $\mathrm{v}$ posledních desetiletích proměnil. Zatímco $\mathrm{v}$ devadesátých letech šlo o nově otevřené téma a řada politiků se k němu vyjadřovala s určitou pokorou a úctou, během následujících let se jejich postoje a s nimi související prohlášení výrazně proměňovala. V současnosti se zdá, že jsme svědky daleko ostřejších vyjádření na adresu Romů a jejich osudů za druhé světové války. V souvislosti s výše řečeným je cílem tohoto textu identifikace a hlavních narativů (a jejich proměny) spojených s letským táborem v české polistopadové politice.

\section{Místa kolektivní paměti a „politické životy mrtvých těl“3}

Instrumentální interpretace minulosti slouží jako významný politický nástroj, který napomáhá vhodnými argumenty podpořit budoucí požadavky současných politiků. Historická pamět' je konstituována a legitimizována vždy právě s ohledem na př́tomnost (a též budoucnost). Pamět' může být chápána jako „nekonečná př́ítomnost“, proces vzpomínání a zapomínání, evokující prostřednictvím opakovaných rituálů neustále znovu a znovu aktuálnost svých příběhů. Národ (či jiné společenství) a jeho minulost bývá často konstruován vůči „někomu jinému“. Kolektivní identita se zpravidla utváří v rámci vztahu vůči někomu, kdo je „jiný“, kdo není součástí kolektivity naší (srov. Eriksen 2010). Vztah vůči jiným je tedy nutným pro konstrukci vlastního já, respektive my (srov. Hroch 2009).

Pamět' a historie, jejich provázanost $\mathrm{s}$ tvorbou národní mytologie a v ní často obsažené obrazy národních přátel, nepřátel a the others (srov. Koštálová 2012), to vše je součástí toho, co se dá nejlépe označit jako soft memory. K tomu, aby mohla tato soft memory plnit svoji funkci, je potřeba, aby byla propojena s tím, co Alexander Etkind (2004 2013) označuje jako hard memory a Pierre Nora jako (1989) jako Lieux de Mémoire. Historický odkaz - at' už ve formě státního svátku, významného dne, kapitoly v učebnici, př́padně zpodobnění na jednom ze státních symbolů představuje nástroj propojující minulost se současností (Wittenberg 2015: 370). Toto pojítko minulosti a současnosti funguje lépe ve chvíli, kdy se na minulost „dá sáhnout“. Tuto úlohu naplňují právě fyzická místa paměti (Munro 2020), která jsou utvářena shora (oficiálně) nebo zdola (neoficiálně) a která mají velmi často silný emocionální rozměr (Moshenska 2020). Tato místa přitom mají několik vzájemně provázaných významů - od materiálního a symbolického, přes funkční a komemorační až k významu politickému. Zjednodušeně lze fyzická místa paměti nahlížet jako zhmotněné reprezentace narativů o událostech a lidech, kteří byli/jsou důležití pro určité společenství (Cingerová a Dulebová 2020). Tato místa tedy mohou v rámci společnosti vést $\mathrm{k}$ posílení konsenzu (a v př́padě existence protichůdných narativ

${ }^{3}$ Některé části této kapitoly vychází za laskavého svolení spoluautora dřívějšího textu (viz Naxera a Krčál 2021). 
samozřejmě i konfliktu) ohledně interpretace minulosti (Tomczuk 2016: 105). Zároveň může odvolávání se k takovým místům sloužit jako zdroj politické mobilizace (srov. Forchtner 2016).

Za tímto účelem je vhodné dosáhnout silného emočního apelu, jinými slovy využít místa paměti k navození silných pocitů (hrdost, strach, smutek, nostalgie) (Mannová 2019: 27). Toho lze dosáhnout např́klad za využití instrumentalizace tzv. trauma sites, která představují nástroj přenášení, dokumentace a reifikace traumatických událostí (Violi 2012: 43) a jsou nástrojem, který může vést na jedné straně ke kulturní a společenské transformaci (např. ve smyslu poučení se; McLean 2010: 355), ale také k politické mobilizaci a vytváření a posilování společenských štěpení, př́ípadně kulturních válek.

Jako příklad práce s trauma sites v českém kontextu lze uvést památníky v Lidicích a v Letech u Písku. Oba dva tyto památníky spojuje to, co Katherine Verdery (1999) označuje jako politiku mrtvých těl (politics of dead bodies), která představují silný zdroj pro politickou mobilizaci. Diskuze probíhající kolem otázky (ne)zrušení vepřína a (ne)vybudování důstojného pomníku v Letech ukazují, že místa paměti mohou mít značný konfliktní potenciál, který vyplývá z propojení odlišných ideologických rámců s připomínanou (nebo zapomínanou) minulostí. Silné a emocionální politické diskuze jsou vedeny i o pomníku v Lidicích. Podobně konfliktní roli mají ale nejen místa, na kterých leží/ležela či trpěla těla reálná, ale též „těla bronzová nebo kamenná“, tedy sochy. Stavba sochy znamená vyjmutí osobnosti z časovosti a její znesmrtelnění (Verdery 1999: 5). Ukázkovým příkladem z českého prostředí jsou spory o nedávné odstranění pražské sochy maršála Koněva.

Jak je vidět z výše uvedeného, místa paměti představují relevantní pole politického soupeření při snaze o prosazení požadované interpretace minulosti. Nejvíce patrné je to $\mathrm{v}$ případě, kdy dochází ke kvalitativní změně politického řádu. Ve chvílích, kdy dochází k zásadním změnám režimu, dojde samozřejmě k výrazným proměnám míst paměti, včetně míst s (metaforickými i reálnými) mrtvými těly. To je dokladem toho, že místa paměti jsou vždy projevem symbolické dominance mocenských institucí, které si uzurpují veřejný prostor a využívají jej pro svoje účely (Mannová 2019: 306), a z jejichž strany je vždy přiřknut nový význam těmto místům často právě ve chvílích, kdy dochází k zásadním změnám politického a společenského kontextu (Mannová 2019: 283). To, co bylo vhodné a kýžené v minulosti (tedy optikou minulého režimu), je již nevhodné a nežádoucí (srov. McLean 2010). To lze mimo jiné vztáhnout ktomu, jakým způsobem političtí představitelé rámovali Lety před a po pádu komunistického režimu. 


\section{Letský tábor ve vyjádření českých politiků}

Po roce 1989 v souvislosti se změnou společenských a politických poměrů stoupl i zájem o politickou historii, jehož cílem bylo mimo jiné zaplnění bílých míst dějin. Pozornosti se tak dostávalo i tématům, která do té doby otevírána nebyla (Kmet’ 2015: 5-6). Jedním z nich byl i romský holokaust. Centrálním tématem debaty se poměrně záhy stal prostor bývalého letského tábora a s ním spojené spory o jeho podobu a poselství. Různé skupiny přisuzují konkrétnímu místu paměti vlastí symbolické postavení a tím se dostávají do vzájemného konfliktu. Pomocí postoje k místu vyjadřují svoje cíle a zájmy a udržují soudržnost skupiny (Oláh 2013: 735). Taková situace nastala v případě Let u Písku, kdy došlo k utváření různých narativů vytvořených na základě konkrétní interpretace minulosti.

\subsection{Začátek diskuze}

Téma romského holokaustu bylo otevřeno zejména v souvislosti se zjištěním novináře Paula Polanského, který víceméně náhodně narazil na informace o existenci koncentračního tábora $\mathrm{v}$ Letech u Písku. Polansky předpokládal, že jím předložené informace o existenci tábora a utrpení internovaných vězňů budou českou společností a vládou reflektovány a že dojde k uctění památky Romů a k vyrovnání se s minulostí, a to nejen s obdobím válečných let, ale i se sedmdesátými lety, kdy byl na místě bývalého tábora postaven vepřín. Česká strana ale tento jednoznačný postoj k minulosti nezastávala (Sniegon 2014: 135). Text s výsledky Polanského bádání uveřejněný v roce 1994 obviňoval českou vládu ze snah zakrýt minulost. Letský tábor v něm byl označen jako výlučně česká záležitost bez vlivu nacistického režimu a počty vězňủ i mrtvých měly dosahovat tisíců (Pařízková 2008: 107). Takovým prohlášením Polansky narušil do té doby víceméně jednotně přijímaný pohled, který český národ vnímal jako jednoznačnou obět' druhé světové války. Na Českou republiku se pak snesla vlna kritiky ze zahraničí poukazující na porušování lidských práv menšin.

V souvislosti s kritikou ze zahraničí a medializací tématu byla česká vláda nucena na situaci reagovat. Výsledkem bylo umístění památníku na místě bývalého koncentračního tábora v Letech u Písku 13. května 1995 spojené s pietní akcí, na níž promluvil tehdejší prezident Václav Havel. V projevu přiznal český podíl viny na genocidě Romů, když upozornil na skutečnost, že nacistickými činiteli zřízený tábor spravovali Češi. Poukázal i na využívání Romů ze strany Čechů jako levné pracovní síly v okolí tábora. Současně ale připomněl i pomoc, které se Romům od jiných Čechů během druhé světové války dostalo. Vinu tak nepřiznal žádnému národu jako celku, ale v případě Němců i Čechů hovořil o konkrétních jednotlivcích, kteří měli na událostech podíl, a nepřistoupil k přijetí kolektivní viny národa. V projevu dále upozornil na zlo totality, kdy nacistická umožnila, aby se tyto události staly, a komunistická na ně dovolila zapomenout. Obě pak propojil se 
současným stavem společnosti, v níž se znovu objevují rasistické tendence a projevy nesnášenlivosti vůči jiným. Pomocí upozornění na negativní historické události, které se nesmí opakovat, představil podobu dnešní společnosti a její problémy. Ty označil jako hrozbu prostřednictvím jejich připodobnění ke zlu nacismu a komunismu. V projevu se obracel i k nutnosti vnímat společnost jako celek, který může být úplný pouze v př́padě, kdy zahrnuje všechny svoje části (Havel 1995). Tím se vymezil proti dělení společnosti na my a oni a romskou minoritu označil za důležitou a neoddělitelnou součást celé společnosti.

Podobně promluvili i další vrcholní politici o dva roky později na pietním setkání v Letech. Ministr bez portfeje Pavel Bratinka se kriticky vyjádřil v souvislosti se zacházením s Romy nejen k nacistickému, ale i ke komunistickému režimu a otevřeně kritizoval existenci vepřína (Sniegon 2014: 143), který i přes odhalení pomníku zůstal stát na svém místě. Otázka jeho odstranění začala být aktuální zejména po prohlášení Bratinky a tehdejšího ministra vnitra Jana Rumla, kteří se zavázali k jeho odstranění. Ruml byl současně i jedním z těch, kteří se snažili o nové trestní stíhání bývalých dozorců, z nichž dva ještě v roce 1997 žili (Sniegon 2014: 143). Během pietního aktu v Letech v květnu 1997 uvedl, že hodlá prostřednictvím svého rezortu záležitost vyšetřit a viníky postavit před soud. Cílem ale podle jeho vyjádření nebylo zejména s ohledem na vysoký věk bývalých dozorců primárně jejich uvěznění, ale dosažení přiznání viny, které by mělo být zásadní pro svědomí celého národa (Gál nedat.). Tato prohlášení a jednání ukazovala na snahu vyrovnat se s minulostí prostřednictvím uznání českého podílu viny na letských událostech a směřovala k umožnění vytvoření místa paměti, které by romský holokaust reprezentovalo jako součást kolektivní paměti nejen Romů, ale celé společnosti.

V roce 1997 vyšla kniha novináře Markuse Papeho A nikdo vám nebude věřit. Pape navázal na Polanského a pro knihu využíval zejména výpovědí přeživších a pamětníků. Podobné je i poselství, kterým byla publikace zakončena, a to otevřená otázka české viny. Pape ale více než vinu na samotném holokaustu zdůraznil situaci po konci druhé světové války. Upozornil, že nejen komunistický režim, který nepotrestal viníky událostí a padesát let po válce na místě postavil vepřín, ale i současná společnost, která umožnila zřídit pomník vedle stále fungujícího vepřína, jsou těmi, kdo se nijak nesnažily a nesnaží památku důstojně uctít (Pape 1997: 125). Lze předpokládat, že i vydání této publikace mělo vliv na podobu debaty a vznik narativů, které následovaly.

\subsection{Vznik nových narativů}

V souvislosti se snahou o odstranění vepřína došlo k posunu v diskuzi nejen o památníku, ale i o životě Romů za druhé světové války a jejich postavení v dnešní společnosti. Stále se sice řada vrcholných politiků vyjadřovala souhlasně k nutnosti vytvoření pietního místa obětem romského holokaustu, ale docházelo i k upozorňování na vysoké ekonomické náklady spojené s demolicí nebo přesunem velkovýkrmny. A objevily se i první snahy o 
definici statusu tábora. Právě zde tak vznikl nejen ekonomický narativ, ale i narativ odmítající letský tábor zařadit do stejné skupiny jako koncentrační a vyhlazovací tábory, který se ale naplno projevil až v roce 2005 a následujících letech.

Nesouhlasně se k likvidaci vepřína jako jeden z prvních vyjádřil letský starosta Jan Zárybnický. Nejprve se soustředil pouze na ekonomické dopady, když upozorňoval, že desítky milionů nutné pro odkup by bylo možné využít lepším zpo̊sobem. Romům navrhl uvolnit jiný obecní pozemek v sousedství táborového hřbitova. Vyjádření napovídá, jak bylo téma romského holokaustu a důležitost důstojného uctění památky jeho obětí vnímáno. Docházelo k marginalizaci kauzy a pozornost se soustředila na neefektivní využití financí. Zároveň se objevila myšlenka, že diskuze by neměla být vnímána pouze jako snaha o podporu romské kolektivní identity a začlenění této části historie do paměti národa (vybudování pomníku, muzea), ale finanční podpora romské menšiny by se měla projevit zejména zlepšením jejich aktuálních životních podmínek (výstavba bytů nebo továrny) a začleněním do většinové společnosti. Později Zárybnický připomněl případný pokles pracovních míst související s likvidací vepřína a nutnost přezkoumat reálný status tábora (Gál nedat.). Docházelo tak nejen k upřednostňování ekonomických dopadů nad vytvořením pietního místa, ale i k prvním snahám o redefinování postavení tábora, které by umožnilo chovat se k prostoru jinak než k podobným místům z období druhé světové války.

V této době se do debaty zapojil i romský aktivista Čeněk Růžička, který se zasazoval o vybudování památníku. Podle něj není přípustné, aby na místě, kde jsou pohřbeni předci dnešních Romů, stál vepřín. České vlády neřešením situace Romy přirovnávají k prasatům. Růžička upozornil na nerovné postavení romské menšiny ve společnosti a snažil se o vytvoření narativu, který by s místem paměti pevně spojil připomínku romského utrpení v době protektorátu. Upozornil i na český původ dozorců, kteří se na internaci Romů podíleli (Gál nedat.), čímž opět upozornil na českou vinu na letských událostech a na odpovědnost českého národa a jeho představitelů nejen za válečné osudy Romů, ale i za současný vzájemný vztah majority a romské menšiny.

V roce 1998 se stal premiérem Miloš Zeman, který ještě před volbami zastával postoj, že vybudování památníku v Letech je nezbytné k uctění památky romských občanů a že by bylo možné vyjednávat i o ceně šesti set milionů korun (Šídlo 1998), což byla částka požadovaná firmou AGPI Písek (Sniegon 2014: 145), která vepřín vlastnila. Zeman tím odmítl finanční náročnost jako důvod neřešení situace, ale jeho postoj se proměnil krátce po volbách, kdy přiznal, že existence vepřína je důležitá pro zaměstnanost v regionu (Šídlo 1998). V krátké době tak Zeman změnil svůj postoj k celé kauze a od nutnosti uctění památky Romů se přiklonil k ekonomickému narativu.

Výraznější prosazení tohoto narativu v diskuzi bylo možné pozorovat i ve vyjádřeních dalších politiků. Časté bylo zejména upozorňování na možnost efektivnějšího využití prostředků. Poslanec za ODS Ivan Langer uvedl, že v současné situaci není vhodné 
vykupovat něčí majetek a stavět nějaký pomník, zatímco by se dané finanční prostředky daly využít například na financování vzdělávacích programů, které by vedly $\mathrm{v}$ budoucnosti k lepšímu soužití romské a většinové komunity (Gál nedat.). Z vyjádření není patrné, zda případné vzdělávací programy byly myšleny pro obě skupiny obyvatel, nebo pouze pro jednu z nich. Nicméně označení „nějaký pomník“ ilustruje důležitost, kterou pro Langera vybudování památníku mělo. Rozdělení společnosti na českou většinu a romskou menšinu odkazuje k dělení na my a ti druzí (srov. Košt'álová 2012) a vyzdvihuje problematický vzájemný vztah, jehož řešení má vyšší prioritu než uctění památky romských předků.

Kromě ekonomického narativu ale byla řešena i otázka české viny. Místopředseda vlády Pavel Rychetský prohlásil, že vepřín v Letech je z dlouhodobého hlediska nemorální a že vláda si je vědoma dluhu vůči romským obětem holokaustu, na němž se podíleli protektorátní kolaboranti (Gál nedat.). Vina českého národa jako celku byla odmítána prostřednictvím důrazu na odpovědnost konkrétních jedinců. S tématem konkrétních viníků pracoval i Polanský ve své další knize Bouře. Prostřednictvím fiktivního příběhu upozorňoval na kolaboraci českých elit s Němci během protektorátu a jejich zneužívání levné pracovní síly romských vězňů pro vlastní účely.4 Tím umožnil vznik sice marginálního, ale stále se objevujícího narativu, který z letských událostí vinil konkrétní osoby a jejich potomky.

V roce 1999 vyšla publikace Historikové a kauza Lety, která reagovala na Polanského a Papeho závěry o české vině. Kromě stručného přehledu o podmínkách v táboře od Ctibora Nečase, který se omezil na shrnutí známých informací o táborových podmínkách, obsahovala publikace i vyhrocenou esej negativně hodnotící Polanského práci s historickými fakty (Slačálek 2013). Podle Valenty (1999: 9) byla kniha určena politikům, médiím a veřejnosti s cílem poskytnout podklady, které povedou k politickým rozhodnutím na základě objektivních údajů, namísto publicistických a mediálních vyjádření ovlivněných emocemi a vědomě i omylem chybně interpretovanými. Valenta reagoval zejména na otázku českého podílu na událostech. Jasně se vymezil proti zaměňování př́ivlastků český a protektorátní v době okupace a opakovaně upozornil, že vládu ani správu země v tomto období nelze pokládat za českou. Kritika mírila proti Papemu, ale zejména Polanskému, který podle Valenty podával nepřesné a zavádějící informace o počtech mrtvých a poměrech v táboře. Část Valentovy stati se věnovala $\mathrm{i}$ nutnosti užívat správnou terminologii $\mathrm{v}$ souvislosti $\mathrm{s}$ letským táborem. Kritizoval publicisty užívaný termín koncentrační pro jakoukoli fázi existence tábora jako neodůvodněný, protože to u veřejnosti vzbuzuje asociace s jinými tábory (např. Osvětimí, Mauthausenem nebo Majdankem) a v nich známými podmínkami, které ale v Letech nikdy

\footnotetext{
${ }^{4}$ Paralela se skutečností byla zřejmá z volby názvu místa i jmen hlavních osob. Protektorátní příběh se odehrával v obci Roky a kolaboranty byli Šavel a Weissenberg, což mělo naznačovat podíl na holokaustu ze strany předků Havla a jeho tehdejš́ího kancléře Karla Schwarzenberga (Sniegon 2014: 142-143).
} 
nepanovaly (Valenta 1999: 14). Odmítnutí české viny i redefinice statusu tábora se staly historicky posvěcenou pravdou, o níž se mohli opřít politici, u nichž bylo možné pozorovat nacionalistické postoje a tendence, např. Václav Klaus nebo Miloslav Ransdorf (Slačálek 2013). To se stalo základem narativů politiků, kteří ho využívali k podpoře svých vlastních postojů směřujících proti romské menšině.

\section{3. „Zasloužená“ genocida}

K dalšímu posunu v debatě došlo v roce 2005, kdy byla Česká republika opět kritizována ze zahraničí za existenci vepřína a nedostatečnou snahu o jeho odstranění. Znovu se ukázalo, že českou debatu o Letech ovlivňovalo vnímání státu a jeho postoje k Romům ze strany mezinárodního (zejména západního) prostředí. Kromě kritiky se ale do debaty o romském holokaustu dostala v tomto období otázka, která měla dopad na podobu diskuze i v následujících letech, a to reálný status tábora a důvod internace osob. Jedním z prvních, kdo odmítl označení tábora za koncentrační, byl europoslanec za KSČM Ransdorf. Prohlásil, že jako historik ví, že se o Letech lže a že na místě žádný skutečný koncentrák nebyl, ale šlo pouze o sběrný a následně internační tábor. Četná úmrtí v táboře byla způsobena převážně špatnými hygienickými podmínkami a následným propuknutím tyfové epidemie (iDnes.cz 2005).

Ransdorf se snažil zpochybnit odpovědnost na událostech ze strany dozorců a tím zcela odmítl diskuzi nad otázkou české viny. Zejména se ale pokusil relativizovat skutečnou funkci letského tábora, v němž zemřela nemalá část jeho vězňů, a pro zbytek internovaných byl pouze přestupní stanicí před převozem do Osvětimi. Zpochybnění statusu tábora umožňovalo dalším politikům i veřejnosti pochybovat o účelnosti výkupu a odstranění vepřína. Tím, kdo podobným vyjádřením začal následný letitý spor mezi politiky, romskými představiteli, historiky i veřejností, byl ale prezident Klaus (Pařízková 2008: 114). Nejenže se přiklonil k tvrzení, že v Letech nešlo o koncentrační tábor, ale prohlásil, že sem byli umist'ováni ne Romové, ale ti, kdo odmítali pracovat. Oběti umíraly zejména na tyfus, a ne $\mathrm{v}$ souvislosti s příčinami, které si se smrtí v koncentračních táborech běžně spojujeme (ihned.cz 2005). Nový narativ pracoval s myšlenkou, že umístění v táboře si internovaní „zasloužili kvůli odporu k práci“. Šlo o jedince, kteří se vymykali většinové společnosti. I když Klaus upozornil, že nešlo pouze o Romy, bylo díky hlavnímu tématu celé diskuze o romském holokaustu jasné, že charakteristika vězňů jako nepracujících se týká zejména Romů. Narativ pracoval i s odmítnutím etnického důvodu internace vězňů $\mathrm{v}$ táboře, což směřovalo $\mathrm{k}$ odmítnutí minimálně tohoto konkrétního zařízení jako součásti romského holokaustu. Snaha o redefinici statusu tábora úzce souvisela i s otázkou podílu Čechů na těchto událostech. Pokud by tábor v Letech koncentrační nebyl a nebyly by v něm internovány osoby na základě etnické příslušnosti, nemohla být vedena diskuze o podílu českého národa na romském holokaustu. 
Vůči Klausovým slovům se ohradila řada osobností, mezi nimi i premiér Jiří Paroubek souhlasící s nezbytným odstraněním vepřína (Pařízková 2008: 114). Klausovo vyjádření odmítl a prohlásil, že tábor jako koncentrační vnímá. Podle něj nelze předstírat, že se nic nestalo, pokud je jasné, že na části společnosti bylo pácháno bezpráví. Z vyjádření vyplývala potřeba vyrovnat se s minulostí a nutnost přijetí odpovědnosti národa i státu na minulých událostech. Současně bylo patrné i vnímání národa jako celku a nevymezování se vůči skupině těch druhých. Část politických elit i veřejnosti narativ snažící se redefinovat postavení letského tábora jasně odmítala, ale současně se ukázal i důvod, proč mohl tento narativ vzniknout a získat si podporu ve zbytku společnosti. Jak uvedl místopředseda Senátu Petr Pithart, v diskuzi nejde o reálný status tábora, ale o slabé veřejné mínění, když veřejnost daná problematika nezajímá (Gál nedat.). Pithart tím upozornil, že většinová společnost problematiku romského holokaustu nevnímala jako součást vlastní historie, a tedy ani vlastní kolektivní identity. Pro velkou část společnosti byly protektorátní osudy Romů osudy těch druhých.

Klausem nastolený narativ naplno propukl v lednu 2006, když nacionalistická krajně pravicová Národní strana nechala na místě bývalého tábora v Letech umístit kámen s textem „Obětem“ jako památník obětem druhé světové války. Předsedkyně strany Petra Edelmannová uvedla, že do tábora byli Němci sváženi Romové i tuláci a asociální živly a takovým není třeba stavět památníky. Uctít je třeba ty, kteří něco dokázali (iDnes.cz 2006). Edelmannová využila negativního stereotypu spojovaného s Romy a vztáhla ho k celé menšině. Označením Romů za nepřizpůsobivé se je pokusila rámovat jako bezcenné a nedůležité pro zbytek „normální“ společnosti. O deportovaných do letského tábora se vyjádřila jako o lidech neschopných práce, bez hygienických návyků a šířících infekční nemoci. Za danou situaci tak nesli vinu oni sami (iDnes.cz 2006).

Narativ o nepřizpůsobivých, kteří si internaci v táboře zasloužili, tím dostal daleko konkrétnější obrysy a i samotné vyjádření bylo oproti Klausovým slovům daleko ostřejší. Kromě odmítání české viny a přisuzování odpovědnosti výhradně Němcům byly za viníky událostí označovány samotné oběti. Jasně bylo v prohlášení patrné rozdělení na my a ti druzí, horší, kteří byli rámováni prostřednictvím negativních stereotypů spojujících Romy s leností a zaostalostí, představující je jako ohrožení zdraví a bezpečnosti zbytku společnosti a jejich separaci jako jediné možné řešení. Současně bylo k prezentaci postojů záměrně využíváno konkrétního místa paměti, i když cílem nebylo přímo přivlastnění narativu, který by s ním měl být spojován, ale spíše snaha o provokaci a rozdmýchání protiromských nálad ve společnosti.

Po odstranění kamene Edelmannová prohlásila, že věří, že bude použit jako základní kámen nového vepř́na, který vybudují všechny cikánské spolky společně a svépomocí. Vyjádření cílilo na posílení stereotypu, že ani současní Romové nepracují a nedělají nic užitečného. K situaci se vyjádřil Havel, který uvedl, že ho mrzí současná debata o statusu tábora naznačující, že letský tábor byl pro internované lepším místem než jiné tábory a že v něm lidé umírali kvůli vlastnímu nedodržování hygieny. Takové 
názory podle něj směřují k tzv. osvětimské lži. Současně odmítl na místě paměti instalaci kamene jako pokrytectví a památník polofašistů, který by tam byl navždy, což je nepřípustné. Vymezil se tím proti konkrétnímu využití místa paměti, které by nesymbolizovalo to, co podle jeho názoru symbolizovat mělo. Uvedl, že kámen byl na místo přivalen polofašisty a sloužil by tedy hlavně jako pomník zastánců této ideologie. Označení Národní strany jako částečně fašistické mělo opět evokovat možné ohrožení demokracie. Edelmannová v reakci uvedla, že odstranění kamene vnímá jako krádež pomníku, čemuž se podle ní nelze divit, když je upřednostňován názor cikánských štváčů oproti postojům historiků z Akademie věd. Tím nejen znovu degradovala romskou menšinu, ale vlastní postoje opřela o výše zmiňované závěry publikace "Historikové a kauza Lety“. Dodala, že v právu jsou členové Národní strany a pouze obhajují pravdu a pamět' národa (Gál nedat.).

\subsection{Dominance ekonomického narativu}

V dubnu 2007 premiér Mirek Topolánek uvedl, že na odstranění vepř́na vláda nemá dostatek financí. Podle něj by se na řešení situace měli kromě státu podílet i kraj, obec, ale i sami Romové (Lidovky.cz 2007). Na kauzu bylo znovu upozorňováno i ze zahraničí, tentokrát ze strany německých a mezinárodních organizací. Kodstranění vepřína a řešení situace vyzvaly nejen Topolánkovu vládu, ale i německou kancléřku a předsedkyni Evropské rady Angelu Merkelovou (Kopp 2007).

Dominanci ekonomického narativu ilustrovalo vyjádření europoslance Jana Březiny. Podle něj by Evropská unie $\mathrm{v}$ př́ípadě, kdy hodlá zasahovat do svrchované pravomoci českých orgánů, měla současně poskytnout i finance potřebné ke zbourání vepřína a stavbě památníku. $V$ opačném př́padě je podle něj rezoluce pouze laciným a populistickým moralizováním (Pražáková 2008). Tímto prohlášením bylo naznačeno, že ekonomické hledisko je, pokud ne přímo jedinou, tou nejzásadnější překážkou v řešení celé záležitosti. Řešením situace byl pověřen ministr pro lidská práva a menšiny Michael Kocáb, který se přiklonil k narativu nastolenému Havlem a cílil na vybudování důstojného památníku v Letech. Podle něj existence vepřína svědčí o ubohosti společnosti, která není schopna vytvořit důstojné pietní místo tam, kde Romové trpěli (Novinky.cz 2009), čímž poukázal na odpovědnost většinové společnosti, a to nejen za historickou křivdu na Romech, ale za způsob, kterým se stavěla současná společnost k aktuální podobě místa paměti. K částečné úpravě místa došlo v roce 2009 a i premiér další vlády Petr Nečas ji s ohledem na finanční možnosti státu považoval za důstojnou (Nosálková 2010). I on prostřednictvím ekonomického narativu obhajoval nemožnost odstranění vepřína. Názor považující vynaložení velkých finančních prostředků za nemožné nebo neúčelné převažoval u politiků i v dalších letech. Podobně konstantní zůstával i postoj většiny romských aktivistů, kteří naopak na odstranění vepř́na trvali a jeho existenci chápali jako neúctu a nezájem většinové společnosti k osudům Romů za protektorátu, ale i jako projev 
jejich vnímání ze strany většiny v současnosti. V roce 2011 např. aktivista Ondřej Giňa uvedl, že romský holokaust $\mathrm{v}$ Česku neskončí do doby, než bude vepřín zbourán (iRozhlas.cz 2011), čímž využil historických událostí ke kritice nerovného postavení romské menšiny.

\subsection{Nové proměny narativů}

Ke změně dominantního narativu a vyostření diskuze došlo postupně v následujících letech. Jedním z důvodů byl opět impuls ze zahraničí, když byla Česká republika v roce 2013 vyzvána výborem OSN pro lidská práva k odstranění vepřína. Řada politiků se ale i tak stavěla k situaci rezervovaně a znovu opakovala ekonomický narativ zdůrazňující příliš vysoké náklady. Např. ministr kultury Jiří Balvín upozornil, že odhadovaná investice do odkupu ve výši čtyři sta milionů je astronomická a že je zbytečné výzvu vnímat jako naději na odstranění vepřína (iRozhlas.cz 2013). Naopak premiér Jiří Rusnok se během projevu na pietním aktu v Letech dotkl podobných témat jako Havel v roce 1995. Stejně jako bývalý prezident využil odkazu událostí v Letech ke zdůraznění současné situace, kterou rámoval jako hrozbu, když prohlásil, že hrůzy holokaustu se nesmí opakovat a zkušenost s nacismem a dalšími nenávistnými ideologiemi by měla být tím, co společnosti umožní nepřipustit další genocidu. Upozornil i na existenci skupin účelově vyvolávajících násilí, kterým je třeba se postavit. Tím propojil nebezpečí související s nacisty v minulosti se současnými skupinami prosazujícími radikální a extremistické názory proti konkrétní části společnosti. Vymezil se proti dělení společnosti na my a oni, když hovořil o utrpení našich spoluobčanů, a věnoval se i otázce české viny, když upozornil, že odpovědnost nelze připisovat pouze okupantům, ale je nutné si připustit český podíl na událostech, a to zejména ze strany protektorátních úřadů, konkrétních dozorců nebo lhostejné veřejnosti, čímž přisoudil odpovědnost za letské události a romský holokaust českému národu jako celku. Odmítl narativ redefinující status tábora, když zdůraznil nedůležitost toho, zda lidé umírali př́mo v Letech následkem chorob a týrání, nebo zemřeli během transportu do vyhlazovacího tábora či přímo v Osvětimi (Rusnok 2013). V souvislosti s odstraněním vepřína označil vysoké ekonomické náklady za relevantní, ale ne jediný problém celé kauzy (Cibulová Vokatá 2013).

$\mathrm{K}$ ekonomickému narativu se naopak přiklonil hejtman Jihočeského kraje Jiří Zimola, podle nějž by romská komunita potřebovala finance na zcela jiné a potřebnější činnosti (Cibulová Vokatá 2013). Kromě neúčelnosti nákladů odmítl vnímat téma romského holokaustu jako celospolečenské. Vybudování památníku v Letech propojil pouze s romskou menšinou, jako by pro zbytek společnosti taková připomínka minulosti žádný význam neměla.

I další vláda v čele s Bohuslavem Sobotkou deklarovala, že na zbourání vepřína není v rozpočtu dostatek financí. Sobotka v roce 2014 uvedl, že peníze by mohly být vynaloženy účelněji a bylo by možné je použít na vzdělávání romských dětí ve 
vyloučených lokalitách. Podle premiéra došlo ke zúžení diskuze na otázku existence vepř́na a bylo opomenuto, že na celé téma by mělo být pohlí̌̌eno i v souvislosti se skrytým rasismem v současné společnosti (Lehmannová 2014). I zde bylo poukazováno na vysoké náklady a upozorňováno na současné problémy a postavení Romů ve společnosti. Znovu zazněly i konkrétní možnosti účelnějšího využití prostředků na podporu Romů, čímž ale Sobotka stejně jako Zimola naznačil, že většinová společnost klade důraz na jiné hodnoty než důstojné připomínání válečného utrpení romské menšiny. Kritiky za své vyjádření se Sobotka dočkal např. od komentátora Martina Fendrycha (2014b), který podotkl, že si premiér vůbec neuvědomuje, že právě prohlášení o ekonomické neefektivnosti vynaložených finančních prostředků ve spojení s upozorněním na narůstající míru rasismu ve společnosti je tím, co samotný rasismus živí. Ten je podle něj podporován zejména neúctou $\mathrm{k}$ romským obětem vyjádřenou zapáchajícím prasečím symbolem. Opačný postoj zastával i Jiří Dienstbier, který se odklonil od ekonomického narativu, když prohlásil, že existence vepřína na místě bývalého koncentračního tábora je neuctivá $\mathrm{k}$ obětem i přeživším a přivítal by, kdyby místo mohlo sloužit pouze $\mathrm{k}$ pietě a nebyla zde provozována zemědělská produkce (Kopecký 2014). Podobně ministr kultury Daniel Herman řekl, že vinu za romský holokaust nelze přičítat pouze fašistickému Německu, ale že koncentrační tábor byl spravován příslušníky české protektorátní policie. Současně bylo podle něj nutné se $s$ dluhy minulosti vyrovnat prostřednictvím jejich správného pojmenování i řešení. Herman na závěr dodal, že kvalita života člověka se neodvíjí od toho, zda se narodil jako Čech, Němec, Žid nebo Rom (ČT24.cz 2014). Oba politici se postavili proti narativu usilujícímu o redefinici statusu tábora, když ho veřejně označili jako koncentrační.

Druhý a výraznější impuls, který debatu o táboře v Letech znovu otevřel a dostal na stránky většiny českých médií, souvisel s vyjádřeními předsedy parlamentní strany Úsvit př́mé demokracie Tomia Okamury, který prohlásil, že v př́ípadě Let u Písku nelze hovořit o koncentračním táboře. Podle Okamury je takový status tábora lží nebo mýtem, vězni zde nebyli internováni na základě rasy, ale kvůli cikánskému způsobu života, což vylučovalo umístění pracujících Romů do tábora. Označovat oběti letského tábora za oběti holokaustu by podle Okamury bylo neúctou ke skutečným obětem reálných koncentračních táborů. Okamura se ztotožnil s narativem, který prostřednictvím útoku na definici statusu tábora a zamítnutím rasového důvodu internace vězňủ odmítal holokaust Romů v Letech jako celek. To podpořil prohlášením, že informace čerpal mj. z výše zmíněné knihy Historikové a kauza Lety, čímž svoje prohlášení opřel o vědeckou autoritu. Úmrtí vězňů Okamura představil jako důsledek stáří nebo infekčních chorob, které si internovaní do tábora přinesli, př́padně bylo zaviněno krutým zacházením ze strany dozorců (Janík a Ř́hová 2014). Situaci v táboře kladl za vinu vězňům a vyčleňoval je z většinové společnosti a řadil do kategorie těch druhých. Odmítnutí českého viny bylo možné spatřovat i v chybějícím upřesnění, že šlo o české dozorce. Vyjádření pochopitelně 
i jasně reflektovalo program strany Úsvit, v němž nechyběl bod požadující spravedlivý sociální systém nepodporující vrstvu žijící pouze ze sociálních dávek a terorizující okolí kriminalitou (Hnutí Úsvit 2013). Kterých občanů se vyjádření týkalo, bylo zřejmé z Okamurova prohlášení z roku 2013, kdy navrhoval vystěhování Romů do Indie a negativní pohled většinové společnosti na romské etnikum přičítal dlouhodobě pěstovanému cikánskému stylu života neslučitelnému s hodnotami civilizovaných zemí (Petřík 2013).

V obou vyjádřeních došlo $\mathrm{k}$ využití negativních stereotypů. Když Okamura upozorňoval na nemoci jako jednu $\mathrm{z}$ př́ćin úmrtí vězňů, evokoval souvislost $\mathrm{s}$ nedostatečnou hygienou této skupiny obyvatel. V druhém výroku se objevilo stereotypní uvažování o zaostalosti a konkrétním nepřizpůsobivém stylu života všech Romů, který ohrožuje zbytek „normální“ společnosti. Okamura byl kritizován např́ic politickým spektrem. Lidovecký poslanec Šimon Heller i několik aktivistů podalo na Okamuru trestní oznámení a od jeho výroků se distancovali i někteří členové hnutí Úsvit. 0 dva dny později se Okamura pokusil svoje slova zmírnit či ospravedlnit. Namísto omluvy nebo odvolání původního prohlášení uvedl, že při označení tábora jako pracovního místo koncentračního vycházel z několika na sobě nezávislých zdrojů. Kromě již zmíněné Valentovy stati se opíral i o Klausovo vyjádření z roku 2005. Letský tábor označil za zločinný, sloužil ke shromáždění Romů před jejich transportem do koncentračních táborů, v nichž byli zavražděni (Šídlo 2014). Kromě opětovné snahy o podpoření vlastních slov prostřednictvím odvolávání se na historické a politické autority, se Okamura znovu pokusil celou diskuzi rozmělnit a zaměřit ji pouze na konkrétní způsob nazývání tábora jako klíčové téma celé kauzy.

Zatímco někteří straničtí kolegové Okamuru podpořili, od dalších sklidil razantní kritiku. K zastáncům patřil Radek Rozvoral, když uvedl, že je nutné věci nazývat pravými jmény. Koncentrační tábor Lety je podle něj nepřesným označením používaným z nepochopení stavu věci, protože na základě historických podkladů lze nalézt řadu rozdílů, které letský tábor od koncentračních odlišují (Rozvoral 2014). Naopak poslanec Milan Šarapatka odsoudil veškeré projevy xenofobie, rasismu nebo politického extremismu a slova předsedy hnutí označil za nešt’astná. Podobně se ke kauze postavil další poslanec hnutí Úsvit Marek Černoch, podle nějž je nutné chápat jako holokaust vyhlazování jakékoli etnické skupiny a není důležité, kdo a jakým způsobem v letském táboře zahynul, ale že $\mathrm{k}$ těmto úmrtím došlo. Oba pak odmítli překrucování historických faktů (EuroZprávy.cz 2014). Vyjádření bylo možné chápat nejen jako snahu distancovat se od kontroverzního postoje stranického předsedy, ale současně je vnímat i jako pokus o vyvážení krajně pravicových postojů hnutí.

Zajímavou reakcí na Okamurovy výroky bylo prohlášení předsedy KSČM Vojtěcha Filipa, který je označil za historicky nepřesné a uvedl, že letský tábor byl zřízen na přání otce Karla Schwarzenberga, který potřeboval pracovní sílu pro likvidaci polomu na svých pozemcích (Parlamentní listy.cz 2014). Filipova kritika nemírila proti obsahu Okamurových slov směrem k romské menšině. Zopakoval závěry Polanského knihy, 
označil viníka minulých událostí a informaci využil proti konkrétnímu politickému oponentovi, když přiřkl kolektivní vinu za existenci letského tábora celému rodu Schwarzenbergů. Tím se vymezil proti Havlem nastoleném narativu o komunistickém podílu viny na poválečném přístupu k romskému holokaustu a letskému místu paměti jako jeho symbolu, který Schwarzenberg dlouhodobě zastával a prosazoval. Podobnou rétoriku použil i poslanec za ČSSD Jandák, když zrušení vepřína označil za největší hloupost, která by se mohla stát. Podle něj je dokázáno, že současná velkovýkrmna nestojí na místě bývalého tábora. Uvedl, že rozhodně nešlo o koncentrační, ale pracovní tábor pro osoby, které pracovat nechtěly. K tomu dodal, že celé zařízení bylo vybudováno na popud „ušlechtilých otců“ Schwarzenberga a Havla (Fendrych 2014a). Ztotožnil se s Okamurovým postojem k romské menšině a vyslal jasný signál o způsobu, kterým by se podle něj mělo s nepracujícími zacházet. Podpořil i narativ prosazovaný komunisty snažící se z letských událostí vinit konkrétní osoby, čímž se pokusil znevážit postoje, jež k celé kauze zastávali jejich potomci.

O další rozruch v kauze se postaral ministr financí Andrej Babiš, když na začátku září 2016 během návštěvy Varnsdorfu prohlásil, že informace v novinách označující tábor v Letech jako koncentrační jsou lživé, protože šlo o pracovní tábor. Svoji větu: „Kdo nepracoval, šup a byl tam,“ doplnil vyjádřením, že v minulosti existovala období, kdy pracovali všichni Romové (euro.cz 2016). Přiklonil se ke Klausovu narativu zpochybňujícímu letský tábor jako součást romského holokaustu a jasně oddělil většinovou společnost my od romské skupiny těch druhých, kterou rámoval prostřednictvím stereotypu o nepracujících. Z vyjádření vyplynulo i naznačení, že $\mathrm{k}$ nepřizpůsobivým osobám je nutné se v současnosti chovat podobně, jako s nimi bylo nakládáno v minulosti. Podobně jako předchozí výrok Okamury bylo i Babišovo vyjádření kritizováno dalšími politiky a řada z nich nepokládala následnou omluvu za dostatečnou. Sobotka Babišovo vyjádření označil za populistické gesto, když upozornil, že předseda hnutí ANO využil návštěvy vyloučené lokality a prostřednictvím lživé historické paralely představil zidealizované poměry letského tábora. Za takové postoje by se podle Sobotky nemusel stydět nejen žádný představitel protektorátu, ale ani sympatizant současné extrémní pravice (ČT24.cz 2016).

Kromě samotné kritiky slov svého politického oponenta (i když šlo o koaličního partnera, sám Babiš hrál po celou dobu jakousi roli opozice uvnitř koalice; srov. Frič a Gyarfášová 2019) se Sobotka pokusil Babiše vykreslit jako nebezpečí pomocí přirovnání jeho názorů k názorům krajně extremistických skupin. Babiš se proti silné vlně kritiky bránil, nicméně i jeho pokus o zmírnění vlastního vyjádření lze ve vztahu k romské menšině hodnotit minimálně jako kontroverzní. Během návštěvy města prý pouze hovořil se starousedlíky a vyptával se jich na soužití s romskou komunitou. Následně sám romské domy navštívil a byl v nich svědkem špíny a nepořádku. Překvapen byl i prrítomností dospělých Romů doma $\mathrm{v}$ dopoledních hodinách, když by $\mathrm{v}$ té době měli být $\mathrm{v}$ práci 
(Holinková 2016). Namísto zmírnění vlastních slov Babiš pouze zopakoval stereotypy o romské nepřizpůsobivosti a nechuti pracovat, které podpořil vlastním očitým svědectvím. Vyjádření tak v důsledku vyznělo jako negativní hodnocení celé romské menšiny. Ke svému původnímu výroku se vrátil v souvislosti se Sobotkovou kritikou. Připomněl, že za svá slova se již několikrát omluvil a je to právě Sobotka, kdo se snaží udržet celou aféru při životě. Premiéra vyzval, aby se sám jel podívat do vyloučené lokality, zatímco on bude řešit odkoupení vepřína a stavbu památníku (EuroZprávy.cz 2016). Kromě poukázání na neschopnost Sobotkovy vlády vyřešit kauzu Lety představil Babiš svého oponenta jako někoho, kdo se zajímá více o vybudování památníku mrtvým Romům než o řešení důležitějších záležitostí, jako je současná napjatá situace mezi většinovou společností a romskou minoritou.

K odkupu vepřína se vyjádřil i prezident Zeman, který požadoval jeho zachování. Demolici prosperujícího podniku považoval za neekonomickou a podle něj by na místě vznikla jen prázdná plocha. Uvedl, že výkup vepřína odmítl kvůli vysoké ceně již jako premiér (Šrajbrová 2017). Ve vyjádření použil opět ekonomický narativ a vynaložení jakýchkoli finančních prostředků označil za plýtvání na něco nepotřebného. Uvedl i to, že na „místě bývalého romského pracovního či možná koncentračního tábora“ by měl být důstojný památník, který tam již ale je, a je možné, že byl vybudován za jeho vlády (Šrajbrová 2017). Kromě manipulace s nedávnou minulostí týkající se vybudování pomníku, který na místě odhalil Havel, obsahovalo vyjádření i příklon k narativu redefinujícímu status tábora. Své postoje ke kauze Lety pak označil za neměnné (Šrajbrová 2017) i přesto, že před volbami v roce 1998 sám zastával názor podporující odkup vepřína bez ohledu na výši finančních nákladů. I Zemanovy výroky sklidily vlnu kritiky. Růžička se vyjádřil prostřednictvím otevřeného dopisu, v němž připomněl nejen český původ dozorců, ale i vybudování vepřína komunisty. Připomněl, že za současnou situaci nesou vinu polistopadové vlády, které kauzu Lety nebyly schopné ukončit, a ministerstvo, jež provoz vepř́na umožňuje dotovat i skrze finance Evropské unie (Růžička 2017). Reagoval využitím narativu pracujícím s otázkou české viny, kterou vztáhl nejen k zástupcům země z období protektorátu, ale provázal ji i s dalšími politickými elitami v jednotlivých obdobích.

\section{6. „Neexistující pseudokoncentrák“}

Odkup vepř́ńna byl vládou schválen v srpnu 2017. Výše investice byla kritizována napříč politickým spektrem, ale k plánu odkupu jako takovému se souhlasně vyjádřila řada politiků, mj. Dienstbier, eurokomisařka Věra Jourová nebo prezidentští kandidáti Michal Horáček a Jiří Drahoš. Horáček se ke kauze Lety vyjádřil již o několik měsíců dříve, když uvedl, že stojí na místě, kde zahynuly naše děti a další lidé byli odvezeni do plynových komor (Romea.cz 2017). V prohlášení zdůraznil, že oběti byly členy naší společnosti, a rezolutně tak odmítl dělení na my a oni. Ostrá kritika snahy o odstranění vepřína naopak 
zazněla např. od místopředsedy KSČM Josefa Skály, který neúčelnost investice podpořil prohlášením, že existovaly horší tábory než letský (Skála 2017). Ekonomický narativ propojil se zpochybněním postavení a funkce romského tábora a odmítl potřebu existence místa paměti v Letech. Ohradil se i proti Výboru pro odškodnění romského holokaustu v ČR, který podle Skály (2017) usiluje i o odškodnění genocidy Romů v době komunismu. Uvedl, že právě za minulého režimu byl romské menšině umožněn civilizační skok a naopak kapitalistická společnost pro ně představuje nebezpečí. Tím odmítl jakoukoli vinu komunistů na nynější podobě místa paměti $v$ Letech. Nesouhlas $\mathrm{s}$ odkupem veprrína vyjádřil i senátor za Severočeši.cz Jaroslav Doubrava, který uvedl, že o holokaustu v souvislosti s letským táborem nelze hovořit, protože do něj byli sváženi cikáni štítící se práce a s kriminální minulostí. Romové podle něj během kočování kradli ve vsích slepice a po druhé světové válce vybydlovali přidělené byty a stejným způsobem žije většina $\mathrm{z}$ nich dodnes (Petř́k 2017). Doubrava se přiklonil k označení samotných vězňů jako viníků, rozdělil společnost na lepší skupinu my pomáhající romské menšině a horší ty druhé, kteří pomoci pouze zneužívali, a to prostřednictvím negativních stereotypů spojovaných $\mathrm{s}$ romským etnikem. Přirovnáním dnešních Romů ke kriminálním živlům a nepracujícím zasluhujícím internaci v letském táboře nejen poukazoval na zbytečnost snahy o jakékoli začlenění této menšiny do většinové společnosti, ale naznačoval i způsob, kterým by se $\mathrm{s}$ Romy měla, podobně jako za protektorátu, současná většinová společnost vyrovnat. Zpochybnil i status tábora, když uvedl, že režim v něm byl relativně volný, místo bylo obehnáno pouze plaňkovým plotem a hlídáno neozbrojenými dozorci. Přeplněnost tábora přičetl na vrub internovaným mužům, kteří si s sebou přivedli do Let i své rodiny, a úmrtí tyfové epidemii jako následku nedostatečné hygieny (Petř́́k 2017). Doubrava nejen posiloval ekonomický narativ zpochybňující účelnost vynaložených prostředků, ale zejména narativ snažící se redefinovat status tábora a zastávající odmítnutí českého podílu na romském holokaustu, a i samotnou existenci místa paměti v prostoru bývalého letského tábora.

Nesouhlasně se vyjádřil i předseda SPD Okamura, ${ }^{5}$ který odkup vepř́na označil za nesmysl a jeho předraženost za šílenství vlády ČSSD, ANO a KDU-ČSL. Finance by podle něj bylo možné využít efektivněji na zlepšení života lidí včetně Romů. Uvedl, že nerozumí, proč je takto řešeno místo, které již pietní úpravu má, zatímco jiným místům připomínajícím mučení a vraždění českých vlastenců a odbojářů se nikdo nevěnuje. Jako př́klad uvedl Kounicovy koleje, kde jsou v současnosti ložnice a koupelny studentů (Petř́ík 2017). Kromě kritiky politických oponentů se Okamura pokusil popř́t paralelu, kterou chov vepřu a jejich odvoz na jatka z místa, na němž byly internovány romské

\footnotetext{
${ }^{5}$ Ostatně pro SPD, stejně jako pro předchozí Okamurův projekt Úsvit přímé demokracie, je vytváření a využívání dělení „my versus oni“ (at’ už vůči Romům nebo muslimům; srov. Stulík a Krčál 2019) typické.
} 
rodiny před transportem do Osvětimi, vyvolával. Užitý příměr ke Kounicovým kolejím byl navíc vzhledem $\mathrm{k}$ historii tohoto místa s příběhem letského vepřína zcela nesrovnatelný.

Výroky, které měly daleko větší ohlas, zazněly v lednu 2018. Předseda SPD uvedl, že tábor v Letech nebyl oplocen a vězni se mohli v podstatě volně pohybovat (Romea.cz 2018), čímž znovu zpochybnil status tábora. V reakci na kritiku Okamura v rámci omluvy uvedl, že jeho vyjádření nebylo přesné. Na místě podle něj plot byl, ale pouze plaňkový a děravý a nikdo ho většinu času nehlídal. Ozbrojeni pak byli dozorci až od února 1943, kdy začali tábor skutečně hlídat, aby neutíkali vězni nakažení tyfem (Lidovky.cz 2018). Nejenže k žádné reálné omluvě za první výrok nedošlo, Okamura navíc znovu popřel roli letského tábora jako součásti holokaustu Romů. Ozbrojení dozorců představil jako jedinou a správnou možnost ochrany společnosti před rizikovou menšinou. Stejný narativ podpořil i Okamurův stranický kolega Miloslav Rozner, který prohlásil, že by „nevyhodil z okna půlmiliardy za likvidaci fungující firmy kvůli neexistujícímu pseudokoncentráku“ (Poláček 2018). V jedné větě dokázal Rozner spojit velmi silně ekonomický narativ i popřít reálný status tábora. Tím dehonestoval nejen samotné oběti letské internace, ale odmítl i jakoukoli důležitost vytvoření připomínky těchto událostí a následného vývoje kauzy pro jejich potomky a celou společnost.

Kritiku za ostrá protiromská vyjádření si vysloužil i Zeman, který uvedl, že i když není zastáncem komunismu, za jejich vlády museli Romové pracovat, a to většinou jako kopáči. V opačném případě byli posláni do vězení jako osoby štítící se práce. Spolu s tím byla připomínána i jeho dřivější vyjádření zpochybňující odkup vepřína nebo prohlášení, že 90 \% nepřizpůsobivých jsou Romové (Kabátová 2018). Zemanovo vyjádření bylo jasným příkladem využití stereotypu o nepracujících Romech, který opřel o konkrétní účelový výklad historie, aby podpořil svoje vlastní současné postoje. Společnost nejen rozdělil na my a oni, ale i naznačil, že by s určitou skupinou obyvatel mělo být zacházeno stejným způsobem, jako tomu bylo za protektorátu nebo komunistického režimu. Spolu s tím částečně zpochybnil i současný režim, když poukázal na skutečnost, že předchozí režimy byly v řešení určitých konkrétních případů efektivnější.

O znevažování romského holokaustu se mluvilo i v souvislosti s vyjádřením poslance za ČSSD Jaroslava Foldyny, který ve spojení s Lety hovořil o vykupování „nějakých prasečáků“, na jejichž místě mají vzniknout pomníky za miliardy. Podle Foldyny není v tomto př́ípadě úcta na místě (Romea.cz 2019). Znovu došlo k propojení ekonomického narativu s narativem zpochybňujícím letský tábor a současně i k odmítnutí Let jako místa paměti spojeného s utrpením Romů. Označením vepř́na jako „nějakého prasečáku" se Foldyna pokusil o zlehčení ústředního tématu celé diskuze a tím i o odmítnutí nejen konkrétních požadavků na jeho zbourání, ale i o nevnímání současných Romů jako důležité součásti společnosti. Dovětek o nepotřebnosti úcty ve spojení s romským holokaustem a jeho obět'mi vyvolával dojem, že je možné i členy současné romské menšiny vnímat jako méněcenné osoby nezasluhující stejného zacházení jako většinová společnost. Ekonomický narativ prezentoval i Filip prohlášením, že odkup a 
likvidace prosperujícího podniku zvedla cenu vepřového masa, a dodal, že šlo o zločin, který má na svědomí Sobotkova vláda (Tvrdoň a Wirnitzer 2019). Spolu s vyzdvihováním neúčelnosti investice relativizoval utrpení Romů, když za zločin označil zrušení vepřína. Kritiku si vysloužil nejen od ČSSD, na níž konkrétně útok míril, ale reagovali i politici dalších stran. Schwarzenberg uvedl, že koncentrační tábor byl spravován Čechy, řada Romů včetně všech zde narozených dětí v něm zahynula a další byli usmrceni v Osvětimi. Připomněl, že to byli komunisté, kdo na místě bývalého tábora nechal v sedmdesátých letech vepřín postavit, a jeho plánované odstranění naopak konečně umožní vzniknout důstojné podobě tohoto pietního místa (Svoboda 2019). Kromě opětovné demonstrace postoje o nezbytnosti vytvoření místa paměti připomínající utrpení Romů jako součásti české identity svým vyjádřením připomněl otázku české viny, s níž je nutné se vyrovnat. Jako další viníky následného vývoje označil komunisty, čímž znovu podpořil původní narativ o nebezpečnosti konkrétní ideologie.

\subsection{Uklidnění diskuze}

Po odkoupení areálu a rozhodnutí o budoucí pietní úpravě místa celá diskuze ochladla a politici se k otázce vraceli víceméně jen v době výročí. Novináři a publicisté naopak kontroverzní vyjádření připomínali ve chvílích, kdy upozorňovali na narůstající rasismus ve společnosti související s nevhodnými nebo i nesnášenlivými výroky politiků ve vztahu $\mathrm{k}$ Romům.

K plánované přeměně místa během piety v roce 2020 vyjádřil ministr kultury Lubomír Zaorálek během vyhlášení výsledků soutěže na budoucí podobu místa. Uvedl, že podobně jako byly zbytky letského tábora zakryty vrstvou půdy, bylo i téma romského holokaustu ve společnosti odmítáno a vnímáno pouze jako okrajové. Nový památník by měl nejen připomínat romské utrpení během druhé světové války, ale i ukazovat na podobu vzájemného soužití mezi Romy a majoritní společností a její proměnu v čase. Uvedl, že věří, že prostřednictvím odhalení kořenů nenávisti a diskriminace a vyvoláním zájmu o lidská práva je možné nalézt cestu ke vzájemnému pochopení mezi romskou a majoritní společností (Earch.cz 2020). Tím se vrátil k původnímu narativu vnímajícím letské události jako součást historie českého národa a upozorňoval na potřebu se s touto minulostí vyrovnat. Zdůrazněním nutnosti vybudování místa paměti s konkrétním poselstvím představil společnost jako jednotnou a odmítal její rozdělování na my a oni.

\section{Závěr}

Diskuze spojená s podobou místa paměti v Letech u Písku probíhala v českém prostředí třicet let. Vliv na její průběh měl bezesporu postoj, který k České republice a jejímu současnému vztahu k romské menšině zaujímaly západní státy. Ten byl nejen impulsem ke vzniku samotné debaty o romském holokaustu, ale díky němu byla v některých fázích 
diskuze i znovu oživována. Zmapování vývoje kauzy doplněné o konkrétní vyjádření politiků týkajících se letského tábora umožnilo identifikovat vznik a vývoj jednotlivých narativů souvisejících s otázkou romského holokaustu i aktuálním postojem různých aktérů k romské menšině a většinové společnosti.

1) Prvním z nich byl narativ, který usiloval o zahrnutí této části minulosti do kolektivní paměti celé společnosti (de facto tak odmítal dělení české společnosti na Čechy a Romy ve smyslu my x oni). Romský holokaust vnímal jednoznačně jako trauma, které nesmí být zapomenuto. Tento narativ propojoval negativní zkušenost s nedemokratickými režimy, které toto trauma umožnily a následně zamlčovaly, se současným stavem společnosti, v němž jako hrozbu rámoval nesnášenlivost a netoleranci související s xenofobií a rasismem. Tento přístup převládal zejména na počátku diskuze, nicméně část politických elit se $\mathrm{k}$ němu v průběhu let opakovaně vracela a převažoval i v poslední fázi diskuze ke kauze Lety.

2) Druhý identifikovaný narativ byl ekonomický. Pracoval s otázkou výše finančních prostředků potřebných $\mathrm{k}$ vyřešení kauzy Lety. $\mathrm{V}$ rámci debaty se postupně rozdělil do několika proudů. $V$ prvním př́ípadě jeho zastánci hovořili pouze o příliš vysokých nákladech, které český stát a vláda nemohly uvolnit z rozpočtu. Postupně se ve vyjádřeních začala objevovat neúčelnost takové investice do památníku a připomínání vhodnějšího využití prostředků pro romskou menšinu. Tímto způsobem narativ pracoval s tématem pouze pohledem většiny a jednostranně očekával přizpůsobení se stávající společnosti pouze ze strany romské menšiny. V závěru diskuze už byla neúčelnost finančních prostředků výrazně spojována zejména s dalším narativem redefinujícím status tábora a popírajícím ho jako součást romského holokaustu. To znamená, že ekonomický narativ sloužil k popření nutnosti využívat prostředky k podpoře integrace Romů do společnosti. Ekonomický narativ částečně pracoval s rozdělením společnosti na my a oni, nicméně v souvislosti s Romy jako těmi druhými alespoň zpočátku nepřistupoval k explicitnímu využívání a vyzdvihování negativních stereotypů. V souvislosti s podobou místa paměti a uchováním konkrétní podoby paměti přiznával nutnost reflektování romského holokaustu jako součásti romské i české kolektivní identity.

3) Třetím a nejvíce kontroverzním narativem byla snaha o redefinici statusu letského tábora a prostřednictvím toho celou diskuzi ke kauze Lety dostat mimo původní kontext. Vyznačoval se odmítáním užívání pojmu koncentrační v souvislosti s táborem, vyzdvihoval období, kdy tábor nebyl čistě romským, a zlehčoval životní podmínky internovaných. Prostřednictvím popírání romského holokaustu cílil na znemožnění vnímat tuto genocidu jako vinu Čechů (Sniegon 2014: 137). Snažil se proto redefinovat vinu za události $\mathrm{v}$ Letech a tu přisuzoval samotným obětem. Podobně přenášel i odpovědnost za současné problémy této menšiny v dnešní společnosti pouze na její členy. Oproti ostatním narativům tento výrazně pracoval s konceptem lepších nás a horších těch druhých, který umocňoval pomocí využití negativních stereotypů spojovaných s Romy. Současně usiloval i o nevnímání tábora jako součásti romského holokaustu jako celku, a 
tedy i odmítal vnímání romského holokaustu jako celospolečenského traumatu a jeho zařazení do kolektivní paměti národa. Proto se stavěl výrazně negativně k možnosti vytvoření místa paměti trvale připomínající utrpení romské menšiny. Tyto postoje byly v diskuzi zviditelněny zejména vyjádřením Klause a následovány převážně politiky, u nichž bylo možné pozorovat nacionalistické tendence doprovázené nesnášenlivými a netolerantními postoji vůči romské menšině nebo dalším marginalizovaným skupinám společnosti.

4) Posledním narativem byl postoj prezentovaný romskými aktivisty. Ten byl víceméně stálý po celou dobu diskuze a usiloval o odstranění vepřína jako neúcty $\mathrm{k}$ památce jejich předků. Zásadní pro něj byla památka mrtvých. Velký důraz na tento symbol souvisel s relativně krátkým časem od utrpení a úmrtí obětí, kdy šlo o živé lidi, které někdo znal, někomu na nich záleželo, někdo se s nimi ztotožňoval (Verdery 1999: 32). Vzhledem k tomu, že někteří pamětníci stále žijí, měla tak pro ně a přímé potomky Romů internovaných $\mathrm{v}$ Letech celá kauza i značně osobní rozměr. Narativ ale zejména propojoval minulé události se současným stavem společnosti, v níž jsou potřeby Romů nedostatečně reflektovány a romská menšina není vnímána jako plnohodnotná součást společnosti. K tomu bylo často využíváno paralely mezi likvidací Romů ze strany českých protektorátních úřadů a velkovýkrmnou vepřo̊ jdoucích následně na porážku. I tento narativ používal rozdělení společnosti na my a oni, když upozorňoval na diskriminaci Romů ze strany většinové společnosti. Současně pracoval zcela jasně s otázkou viny. Tu přisuzoval nejen konkrétním jedincům, kteří se na existenci a událostech v letském táboře přímo podíleli, ale zejména české společnosti stavící se k problému dlouhodobě negativně a odmítavě. Narativ cílil na zařazení romského holokaustu do paměti Romů, ale současně požadoval i české vyrovnání se s minulostí prostřednictvím uvědomění si podílu viny na událostech a potřebu jejího odčinění ze strany Čechů. Usiloval tak o to, aby se toto kolektivní trauma stalo součástí romské i české identity koncentrované v konkrétním místě paměti v Letech u Písku.

Kromě identifikace jednotlivých narativů lze na základě zmapování celé diskuze pozorovat i vývoj, kterým od svého počátku do současnosti prošla. V některých obdobích sice převládl konkrétní pohled na způsob, kterým by měl být romský holokaust a letský tábor vnímán, většinou se ale pohledy na tuto historii a podobu místa paměti značně odlišovaly a s přibývající délkou diskuze se dostávaly do stále větší opozice. Jednotlivá vyjádření pak lze hodnotit jako kontroverznější a reakce na ně jako ostřejší. Podobně lze sledovat i vývoj $\mathrm{v}$ rétorice samotných politických elit. Zatímco někteří byli ve svých vyjádřeních konzistentní a na svých názorech trvali (Schwarzenberg, Okamura), jiní postupně využili k podpoře svých postojů více představených narativů (Zeman). 
Spory o (ne)vystavění letského památníku dobře zapadají do kontextu vývoje obdobných sporů vdalších zemích, včetně konsolidovaných demokracií. Právě v nich se $\mathrm{v}$ přinejmenším posledních dvaceti letech staly spory o minulost vyhrocenější, stejně tak se zintenzivnila jejich úloha v rámci identitárních politik. At’ už šlo o první impulsy, které přišly spíše zleva (např. dekonstrukce velkých národních příběhů nebo důraz na práva menšin), nebo následné (do značné míry obranné) impulsy zprava (odmítání liberálního universalismu nebo kritického hodnocení vlastní minulosti), které do určité míry souvisely s tím, co Fukuyama (2018) označil jako „požadavek na důstojnost“ nebo „politiku rozhořčení“. Ke střetům pravice a levice se následně přidaly i kulturní a identitární spory uvnitř pravice a levice.

Podobný vývoj zaznamenáváme (s určitým opožděním) i v českém prostředí - po zdánlivém konsensu 90. let (který byl daný mimo jiné klidným, tedy „sametovým“, přechodem k demokracii; viz např. Sekerák 2018) se postupně začaly (i v souvislosti s taktéž opožděným nástupem požadavků kulturní levice) prohlubovat nejen spory o výklad komunistického režimu a různých verzí „revisionismu“ (Buben a Štefek 2021), ale též o starší dějiny nebo jiné aspekty identity (Holý 2010), vůči kterým doposud existoval zdánlivý konsensus. Vynořily e staré a k tomu objevily nové spory o výklad dějin a pojetí české identity (Chlup 2020). Dějiny tak plně vstoupily do politického procesu.

Případ diskuze o tom, zda zbořit vepřín a vybudovat památník, to jen potvrzují. Zejména otázky poměrně vyhrocených střetů kolem přiznání či popření „české viny“ nebo toho, zda jsou či nejsou Romové součástí české společnosti (a případně též toho, zda tábor skutečně nebyl zaslouženým trestem pro ty, co „nechtěli pracovat“), plně ukazují propojení dějin a současné politiky. Daný střet se tak nevede pouze o výklad jedné historické epochy, jde o střet inherentní současné české politice a společnosti. Dějiny jsou tedy bojištěm pro bitvy současnosti.

\section{Literatura a seznam zdrojů}

Bernstein, S. 2015. „Remembering war, remaining Soviet: Digital commemoration of World War II in Putin's Russia." Memory Studies 9 (4): 422-436. https://doi.org/10.1177/1750698015605573

Buben, R. a Štefek, M. 2021. „Konceptuální labyrinty. Kolik pojetí totalitarismu znáš, tolikrát jsi revizionistou?" Soudobé dějiny (on-line first).

Cibulová Vokatá, J. 2013. „Jiří Rusnok na pietním shromáždění v Letech přislíbil řešit odstranění vepřína.“ iRozhlas.cz. 2. 8. 2013. [online]. [cit. 15. 1. 2021]. Dostupné z: https://www.irozhlas.cz/zpravydomov/jiri-rusnok-na-pietnim-shromazdeni-v-letech-prislibil-resit-odstraneniveprina_201308020213_kpracharova

Cingerová, N. a Dulebová, I. 2020. „Rock Beats the Wall? On Commemorative Practices in Post-Soviet Russia." Journal of Nationalism, Memory \& Language Politics $14 \quad$ (1): 71-91. https://doi.org/10.2478/jnmlp-2020-0001 
ČT24.cz 2014. „Herman: Problém vepřína v Letech vyřešíme.“ Česká televize. 1. 8. 2014. [online]. [cit. 2. 5. 2020]. Dostupné z: https://ct24.ceskatelevize.cz/domaci/1023450-herman-problem-veprina-vletech-vyresime

ČT24.cz. 2016. „Parazituje na problémech soužití s Romy, opřel se Sobotka do Babiše.“ Česká televize. 2. 9. 2016. [online]. [cit. 2. 5.2020]. Dostupné z: https://ct24.ceskatelevize.cz/domaci/1894754parazituje-na-problemech-souziti-s-romy-oprel-se-sobotka-do-babise

D'Orsi, L. 2015. „Trauma and the Politics of Memory of the Uruguayan Dictatorship.“ Latin American Perspectives 42 (3): 162-179. https://doi.org/10.1177/0094582X15581162

Diner, D. 2003. „Restitution and Memory - The Holocaust in European Political Cultures.“ New German Critique 90: 36-44. https://doi.org/10.2307/3211106

Earch.cz. 2020 „Pieta uprostřed lesa. V mezinárodní soutěži na památník holokaustu Romů a Sintů v Letech zvítězilo studio Terra Florida a Atelier Světlík." Earch.cz. 10. 6. 2020. [online]. [cit. 13.1. 2020]. Dostupné z: $\quad$ https://www.earch.cz/cs/revue/pieta-uprostred-lesa-v-mezinarodni-soutezi-na-pamatnikholokaustu-romu-sintu-v-letech

Eriksen, T. H. 2010. Ethnicity and Nationalism. Anthropological Perspectives. London/New York: Pluto Press. Etkind, A. 2004. „Hard and Soft in Cultural Memory: Political Mourning in Russia and Germany.“ Grey Room 16: 36-59. https://doi.org/10.1162/1526381041887439

Etkind, A. 2013. Warped Mourning: Stories of the Undead in the Land of the Unburied. Stanford: Stanford University Press. https://doi.org/10.1353/imp.2013.0096

euro.cz. 2016. „Popřel Babiš holokaust? Lety u Písku podle něj koncentrák nebyly.“ Euro. 1. 9. 2016. [online]. [cit. 2. 5. 2020]. Dostupné z: https://www.euro.cz/politika/poprel-babis-holokaust-lety-u-pisku-podlenej-koncentrak-nebyly-1302705

EuroZprávy.cz. 2014. „Okamurovi se bouří klub. Poslanci odmítají jeho zlehčování nacistických zločinů.“ EuroZprávy. 9. 8. 2014. [online]. [cit. 2. 5. 2020]. Dostupné z: https://eurozpravy.cz/domaci/politika/99715-okamurovi-se-bouri-klub-poslanci-odmitaji-jehozlehcovani-nacistickych-zlocinu/

EuroZprávy.cz. 2016. „Babiš navštíví Lety, chce sehnat peníze na památník. Sobotkovi poslal ostrý vzkaz.“ EuroZprávy. 4. 9. 2016. [online]. [cit. 2. 5. 2020]. Dostupné z: https://eurozpravy.cz/domaci/politika/167588-babis-navstivi-lety-chce-sehnat-penize-na-pamatniksobotkovi-poslal-ostry-vzkaz/?fbclid=IwAR1rG1dBIgl5-OdkUnImi480nXv2F_tMhHjBS_LftNDu9dMSaP5xhXykNA

Fendrych, M. 2014a. „Český rasismus smrdí. Okamurovi a Jandákovi ten smrad voní.“ Aktuálně.cz. 4. 8. 2014. [online]. [cit. 2. 5. 2020]. Dostupné z: https://nazory.aktualne.cz/komentare/cesky-rasismus-smrdiokamurovi-a-jandakovi-ten-smrad-nevadi/r e8a7fac01bbc11e4a8700025900fea04/

Fendrych, M. 2014b. „Chrochtající prasata symbolizují naše vyrovnání s minulostí.“ Aktuálně.cz. 12. 5. 2014. [online]. [cit. 2. 5. 2020]. Dostupné z: https://nazory.aktualne.cz/komentare/chrochtajici-prasatasymbolizuji-nase-vyrovnani-s-minulosti/r 9a8c9a9ed9b811e399e0002590604f2e/

Forchtner, B. 2016. Lessons from the Past? London: Palgrave Macmillan. https://doi.org/10.1057/978-1137-48322-5 
Frič, P. a Gyarfášová, O. 2019. „The Rise of the Politics of Emotions: Anti-elitism and Anti-Corruptism as Traits of Czech and Slovak Populist Parties.“ Politické vedy 22 (4): 221-246. https://doi.org/10.24040/politickevedy.2019.22.4.221-246

Fukuyama, F. 2018. Identity: The Demand for Dignity and the Politics of Resentment. New York: Farrar, Straus and Giroux.

Gál, F. nedat. Kecy v kleci. [online]. [cit. 2. 5. 2020]. Dostupné z: https://www.fedorgal.cz/g-plus-g/romskyholocaust/analyza-let.pdf

Garsztecki, S. 2012. „Memories of the Holocaust and the Jewish heritage in Belarus and Poland.“ In: Z. Krasnodebski, S. Garsztecki a R. Rüdiger (eds.). Politics, History and Collective Memory in East Central Europe. Hamburg: Reinhold Krämer Verlag, 197-219.

Havel, V. 1995. „Projev prezidenta republiky Václava Havla při odhalení pomníku Romům na místě internačního cikánského tábora a u př́ležitosti 50. Výročí ukončení II. Světové války v Evropě." Romea.cz. 5. 10. 2016. [online]. [cit. 2. 5. 2020]. Dostupné z: http://www.romea.cz/cz/zpravodajstvi/vaclav-havelpred-20-lety-v-letech-u-pisku-hruzy-ktere-plodi-rasismus-zname-nedopustme-aby-se-opakovaly

Hnutí Úsvit. 2013. Program hnutí. [online]. [cit. 2. 5. 2020]. Dostupné z: https://web.archive.org/web/20131025011909/http://www.hnutiusvit.cz/program-hnuti/

Holinková, P. 2016. „'Že tábor v Letech byl koncentrák, to je lež,' pobouřil Babiš veřejnost. Je to vytrženo z kontextu, brání se." iRozhlas.cz. 2. 9. 2016. [online]. [cit. 2. 5. 2020]. Dostupné z: https://www.irozhlas.cz/zpravy-domov/-ze-tabor-v-letech-byl-koncentrak-to-je-lez-pobouril-babisverejnost-je-to-vytrzeno-z-kontextu-brani-se-_201609021704_pholinkova

Holý, L. 2010. Malý český člověk a skvělý český národ: Národní identita a postkomunistická transformace společnosti. Praha: SLON.

Hroch, M. 2009. Národy nejsou dílem náhody. Praha: SLON.

Chlup, R. 2020. „Competing myths of Czech identity.“ New Perspectives 28 (2): 179-204. https://doi.org/10.1177/2336825X20911817

iDnes.cz. 2005. „Uhl žaluje Ransdorfa za slova o táboře v Letech.“ iDnes.cz. 10. 5. 2005. [online]. [cit. 2. 5. 2020]. Dostupné z: https://www.idnes.cz/zpravy/domaci/uhl-zaluje-ransdorfa-za-slova-o-tabore-vletech.A050510_131611_domaci_jpl

iDnes.cz. 2006. „Šéfka Národní strany: Bráním Čechům, co je české.“ iDnes.cz. 17 1. 2006. [online]. [cit. 2. 5. 2020]. Dostupné z: https://www.idnes.cz/zpravy/domaci/sefka-narodni-strany-branim-cechum-co-jeceske.A060117_103404_domaci_nel

ihned.cz. 2005. „Klaus v názoru na tábor v Letech souhlasí s Ransdorfem.“ ihned.cz. 14. 5. 2005. [online]. [cit. 2. 5. 2020]. Dostupné z: https://domaci.ihned.cz/c1-16147640-klaus-v-nazoru-na-tabor-v-letechsouhlasi-s-ransdorfem

iRozhlas.cz. 2011. „Při pietě v Letech se znovu volalo po odstranění vepřína.“ ČT24. 13. 5. 2011. [online]. [cit. 2. 5. 2020]. Dostupné z: https://ct24.ceskatelevize.cz/domaci/1266264-pri-piete-v-letech-se-znovuvolalo-po-odstraneni-veprina

iRozhlas.cz. 2013. „Uzavřete vepřín v Letech, vyzvala OSN Českou republiku.“ iRozhlas.cz. 25. 7.2013. [online]. [cit. 2. 5. 2020]. Dostupné z: https://radiozurnal.rozhlas.cz/uzavrete-veprin-v-letech-vyzvalaosn-ceskou-republiku-7184129 
Janík, M. a Ř́hová, T. 2014. „'Koncentrák to nebyl,' popírá Okamura romský holocaust v Letech.“ Echo24.cz. 2. 8. 2014. [online]. [cit. 2. 5. 2020]. Dostupné z: https://echo24.cz/a/wZpRG/koncentrak-to-nebylpopira-okamura-romsky-holocaust-v-letech

Kabátová, Š. 2018. „Že fackování Romů v práci za komunismu fungovalo? Zeman zhoršuje etnické napětí, ř́́ká politolog." Lidovky.cz. 28. 9. 2018. [online]. [cit. 2. 5. 2020]. Dostupné z: (https://www.lidovky.cz/domov/ze-fackovani-romu-v-praci-za-komunismu-fungovalo-zemanzhorsuje-etnicke-napeti-rika-politolog.A180927_161505_ln_domov_sk

Kmet', N. 2015. „Politická história a spoločnost' po roku 1989.“ Studia Politica Slovaca 8 (2): 5-21.

Kopecký, J. 2014. „Dienstbier: Prasečák na místě, kde trpěli lidé, je neúctou k obětem.“ iDnes.cz. 31. 7. 2014. [online]. [cit. 2. 5. 2020]. Dostupné z: https://www.idnes.cz/zpravy/domaci/ministr-dienstbier-budeusilovat-o-to-aby-v-letech-nebyl-prasecak.A140731_145607_domaci_kop

Kopp, M. 2007. „Německé organizace apelují na přemístění vepř́na z Let.“ iRozhlas.cz. 13. 6. 2007. [online]. [cit. 2. 5. 2020]. Dostupné z: https://www.irozhlas.cz/zpravy-svet/nemecke-organizace-apeluji-napremisteni-veprina-z-let_200706131259_mkopp

Koštálová, P. 2012. Stereotypní obrazy a etnické mýty. Kulturní identita Arménie. Praha: SLON.

Lehmannová, R. 2014. „Ani Sobotkova vláda zřejmě nenajde peníze na likvidaci vepřrina v Letech u Písku.“ iRozhlas.cz. 10. 5. 2014. [online]. [cit. 2. 5. 2020]. Dostupné z: https://www.irozhlas.cz/node/5929943

Lidovky.cz. 2007. „Topolánek: Na Lety peníze nebudou.“ Lidovky.cz. 6. 4. 2007. [online]. [cit. 2. 5. 2020]. Dostupné $\quad$ z: $\quad$ https://www.lidovky.cz/domov/topolanek-na-lety-penizenebudou.A070406_121322_In_domov_vvr

Lidovky.cz. 2018. „Tábor pro Romy v Letech nebyl hlídaný, míní Okamura. Za plot se omluvil.“ Lidovky.cz. 2. 2. 2018. [online]. [cit. 2. 5. 2020]. Dostupné z: https://www.lidovky.cz/domov/okamura-na-facebookuzopakoval-ze-tabor-pro-romy-v-letech-nebyl-koncentracni.A180202_131149_ln_domov_ele

Mannová, E. 2019. Minulost' ako supermarket? spôsoby reprezentácie a aktualizácie dejín Slovenska. Bratislava: VEDA.

McLean, I. 2010. „Political Science and History: Friends and Neghbours.“ Political Studies 58: 354-367. https://doi.org/10.1111/j.1467-9248.2009.00826.x

Moshenska, G. 2020. „Memorials that Lurk and Pounce.“ In: C. Gilbert, K. McLoughlin a N. Munro (eds.). On Commemoration. Global Reflections upon Remembering War. Berlin: Peter Lang, 151-156.

Munro, N. 2020. „Introduction: More than Stone - Finding Ourselves in Our Monuments.“ In: C. Gilbert, K. McLoughlin a N. Munro (eds.). On Commemoration. Global Reflections upon Remembering War. Berlin: Peter Lang, 113-121.

Naxera, V. a Krčál, P. 2021 (in print). Celebrating Liberation: The Commemoration and Instrumentalisation of the End of the Second World War in Contemporary Czech and Slovak Politics. Berlin: Peter Lang.

Nora, P. 1989. „Between Memory and History: Les Lieux de Mémoire.“ Representations 26: 7-24. https://doi.org/10.2307/2928520

Nosálková, T. 2010. „Nečasova vláda nahlas říká: Vepřín v Letech se bourat nebude.“ Lidovky.cz. 8. 10. 2010. [online]. [cit. 2. 5. 2020]. Dostupné z: https://www.lidovky.cz/domov/necasova-vlada-nahlas-rikaveprin-v-letech-se-bourat-nebude.A101007_211542_ln_domov_tsh 
Novinky.cz. 2009. „Kocáb začal úřadovat, chce zrušit vepř́ín v Letech.“ Novinky.cz. 24. 1. 2009. [online]. [cit. 2. 5. 2020]. Dostupné z: https://www.novinky.cz/domaci/clanek/kocab-zacal-uradovat-chce-zrusitveprin-v-letech-40217555

Oláh, G. 2013. „Kolektivní pamět', prostor a významy. Případ náměstí svobody v Budapešti.“ Sociologický časopis 49 (5): 729-750. https://doi.org/10.13060/00380288.2013.49.5.9

Pape, M. 1997. A nikdo vám nebude věřit. Dokument o koncentračním táboře Lety u Písku. Praha: GplusG.

Parlamentnílisty.cz. 2014. „V Letech nebyl žádný koncentrák, řekl nám Okamura. Schwarzenberg to chce řešit, Filip zmiňuje jeho otce." Parlamentní listy. 4. 8. 2014. [online]. [cit. 2. 5. 2020]. Dostupné z: https://www.parlamentnilisty.cz/arena/monitor/V-Letech-nebyl-zadny-koncentrak-rekl-nam-

Okamura-Schwarzenberg-to-chce-resit-Filip-zminuje-jeho-otce-329457

Pařízková, J. 2008. „Bývalý internační tábor pro Romy v Letech u Písku a jeho poválečná historie.“ Romano džaniben 15 (3): 98-118.

Petřík, L. 2013. „Cikáni, vystěhujte se, napsal Okamura a začal nářez. I kníže se zapojil.“ Parlamentní listy. 1. 7. 2013. [online]. [cit. 2. 5. 2020]. Dostupné z: https://www.parlamentnilisty.cz/arena/monitor/Cikanivystehujte-se-napsal-Okamura-a-zacal-narez-I-knize-se-zapojil-277312

Petřík, L. 2017. „Neuvěřitelná hanebnost Hermana a Sobotkova prasárna. Za tohle půjdou do pyžama. Stropnický, kníže, Okamura či Doubrava se nám vyjádřili k odkupu vepřína v Letech." Parlamentní listy. 31. 2017. [online]. [cit. 2. 5. 2020]. Dostupné z: https://www.parlamentnilisty.cz/zpravy/kauzy/Neuveritelna-hanebnost-Hermana-a-Sobotkovaprasarna-Za-tohle-pujdou-do-pyzama-Stropnicky-knize-Okamura-ci-Doubrava-se-nam-vyjadrili-kodkupu-veprina-v-Letech-510405

Poláček, D. 2018. „Tábor v Letech je neexistující pseudokoncentrák, tvrdí Rozner z SPD. Omluvu po Okamurovi chce i židovská obec." ihned.cz. 5. 2. 2018. [online]. [cit. 2. 5. 2020]. Dostupné z: https://domaci.ihned.cz/c1-66039630-tabor-v-letech-je-neexistujici-pseudokoncentrak-tvrdi-roznerz-spd-omluvu-po-okamurovi-chce-i-zidovska-obec

Probst, L. 2003. „Founding Myths in Europe and the Role of Holocaust.“ New German Critique 90: 45-58. https://doi.org/10.2307/3211107

Roediger, H. L., Abel, M., Umanath, S., Schaffer, R. A., Fairfield, B., Takahashi, M. a Wertsch, J. V. 2019. "Competing national memories of World War II." Proceedings of the National Academy of Sciences of the United States of America 119 (34): 16678-16686. https://doi.org/10.1073/pnas.1907992116

Romea.cz. 2017. „Čeští politici komentují možný konec vepřína v Letech. Prezidentský kandidát Drahoš je rád, že prasečák zmizí." Romea.cz. 11. 8. 2017. [online]. [cit. 2. 5. 2020]. Dostupné z: http://www.romea.cz/cz/zpravodajstvi/domaci/cesti-politici-komentuji-mozny-konec-veprina-vletech-prezidentsky-kandidat-drahos-je-rad-ze-prasecak-zmizi

Romea.cz. 2018. „Okamura v den památky obětí holocaustu opět zpochybnil hrůzy páchané v táboře Letech, Muzeum romské kultury žádá omluvu." Romea.cz. 29. 1. 2018. [online]. [cit. 2. 5. 2020]. Dostupné z: http://www.romea.cz/cz/zpravodajstvi/domaci/okamura-v-den-pamatky-obeti-holocaustu-opetzpochybnil-hruzy-pachane-v-tabore-letech-muzeum-romske-kultury-zada-omluvu

Romea.cz. 2019. „"A k čemu úcta?" Poslanec ČSSD Foldyna zlehčoval oběti romského holocaustu. Lhal, že "mauzoleum" - památník v Letech - bude stát miliardy." Romea.cz. 19. 1. 2019. [online]. [cit. 2. 5. 2020]. 
Dostupné z: http://www.romea.cz/cz/zpravodajstvi/domaci/a-k-cemu-usta-poslanec-cssd-foldynazlehcoval-obeti-romskeho-holocaustu.-lhal-ze-mauzoleum-pamatnik-v-letech-bude-stat

Rozvoral, R. 2014. „Pracovní tábor v Letech nebyl koncentračním táborem, ale ...“ iDnes.cz/blog. 10. 8. 2014. [online]. [cit. 2. 5. 2020]. Dostupné z: https://rozvoral.blog.idnes.cz/blog.aspx?c=421370

Rusnok, J. 2013. „Premiér: Vzpomínkové setkání je pro nás výzvou, abychom se s rasistickými předsudky nesmírili.“ Vláda ČR. 1. 8. 2013. [online]. [cit. 2. 5. 2020]. Dostupné z: https://www.vlada.cz/cz/clenovevlady/premier/projevy/premier-vzpominkove-setkani-je-pro-nas-vyzvou--abychom-se-s-

rasistickymi-predsudky-nesmirili-109311/

Růžička, Č. 2017. „Čeněk Růžička reaguje na prezidenta Zemana: Stydím se za vás, za vraždy Romů mohou české protektorátní instituce.“ Romea.cz. 1. 7. 2017. [online]. [cit. 2. 5. 2020]. Dostupné z: http://www.romea.cz/cz/publicistika/komentare/cenek-ruzicka-reaguje-na-prezidenta-zemanastydim-se-za-vas-za-vrazdami-romskych-zen-muzu-a-deti-mohou-ceske-protektoratni

Sekerák, M. 2018. „The Velvet Revolution and the Centre/Periphery Model: The Case of South Bohemia.“ Politické vedy 21 (4): 8-29. https://doi.org/10.24040/politickevedy.2018.21.4.8-29

Skála, J. 2017. „Pomník místo vepřína a šaškovská koruna.“ Haló noviny. 25. 8. 2017. [online]. [cit. 2. 5. 2020]. Dostupné z: http://www.halonoviny.cz/articles/view/46084928

Slačálek, O. 2013. „Jednou za rok.“ Nový prostor 2013 (417). [online]. [cit. 2. 5. 2020]. Dostupné z: http://novyprostor.cz/clanky/417/jednou-za-rok

Sniegon, T. 2014. Vanished history: the Holocaust in Czech and Slovak historical culture. New York/Oxford: Berghahn Books.

Stulík, O. a Krčál, P. 2019. „Surfování na migrační vlně v době populismu: Sekuritizace migrace ze strany poslanců Parlamentu České republiky." Acta Politologica 11 (2): 1-17. https://doi.org/10.14712/18038220/8_2019

Svoboda, M. 2019. „Rozzuřený Schwarzenberg: V koncentráku v Letech hlídali čeští dozorci. Je vepřo knedlo zelo důležitější než oběti?“ EuroZprávy.cz. 12. 8. 2019. [online]. [cit. 2. 5. 2020]. Dostupné z: https://eurozpravy.cz/domaci/politika/265744-rozzureny-schwarzenberg-v-koncentraku-v-letechhlidali-cesti-dozorci-je-vepro-knedlo-zelo-dulezitejsi-nez-obeti/

Šídlo, J. 1998. „Po Beranovi je na tahu Zeman.“ Respekt. 30. 11. 1998. [online]. [cit. 2. 5. 2020]. Dostupné z: https://www.respekt.cz/tydenik/1998/49/po-beranovi-je-na-tahu-zeman?issueId=506

Š́́dlo, J. 2014. „Tomio Okamura odmítl kritiku svého výroku o romském táboře v Letech.“ iRozhlas.cz. 4. 8. 2014. [online]. [cit. 2. 5. 2020]. Dostupné z: https://www.irozhlas.cz/node/5943001

Šrajbrová, M. 2017. „Facka romským obětem holokaustu, kritizují aktivisté Zemana, který chce zachovat vepř́n v Letech." Aktuálně.cz. 30. 6. 2017. [online]. [cit. 2. 5. 2020]. Dostupné z: https://zpravy.aktualne.cz/domaci/veprin-prosperuje-a-dustojny-pamatnik-uz-v-letech-stoji$\mathrm{rekl} / \mathrm{r} \sim \mathrm{a} 9 \mathrm{a} 3249 \mathrm{e} 5 \mathrm{da} 411 \mathrm{e} 793 \mathrm{~d} 0002590604 \mathrm{f} 2 \mathrm{e} /$

Tomczuk, S. J. 2016. „Contention, consensus, and memories of communism: Comparing Czech and Slovak memory politics in public spaces, 1993-2012." International Journal of Comparative Sociology 57 (3): 105-126. https://doi.org/10.1177/0020715216658187 
Tvrdoň, J. a Wirnitzer, J. 2019. „Za zdražení masa může podle šéfa KSČM prodej vepřína v Letech. Data to vyvracejí." DeníkN.cz. 7. 8. 2019. [online]. [cit. 2. 5. 2020]. Dostupné z: https://denikn.cz/176835/zaceny-masa-muze-podle-sefa-kscm-prodej-veprina-v-letech-data-to-ovsem-vyvraceji/?ref=tema

Valenta, J. 1999. „Mediální debata o táboru v Letech očima historika.“ In: Historikové a kauza Lety. Praha: Academia, 11-15.

Verdery, K. 1999. The Political Lives of Dead Bodies. New York: Columbia University Press.

Violi, P. 2012. „Trauma Sites useums and Politics of Memory: Tuol Sleng, Villa Grimaldi and the Bologna Ustica Museum.“ Theory, Culture \& Society 29 (1): 36-75. https://doi.org/10.1177/0263276411423035

Wittenberg, J. 2015. „Conceptualizing Historical Legacies.“ East European Politics and Societies and Cultures 29 (2): 366-378. https://doi.org/10.1177/0888325415577864 